Черненко Е.Ф. Энергетическая дипломатия: учебное пособие для бакалавриата и магистратуры. М.: Издательство «Юрайт», 2018. - 139 с.

\author{
И.Ф. Шириязданова
}

Российский университет дружбы народов, Москва, Российская Федерация

\title{
Chernenko, E.F. (2018). Energy Diplomacy. Moscow: Urait publ., 139 p. (In Russian)
}

\author{
I.F. Shiriiazdanova \\ RUDN University, Moscow, Russian Federation
}

\begin{abstract}
Для цитирования: Шириязданова И.Ф. Рецензия: Черненко Е.Ф. Энергетическая дипломатия: учебное пособие для бакалавриата и магистратуры. - М.: Издательство «Юрайт», 2018. - 139 с. // Вестник Российского университета дружбы народов. Серия: Международные отношения. 2019. T. 19. № 3. С. 512-514. DOI: 10.22363/2313-06602019-19-3-512-514
\end{abstract}

For citations: Shiriiazdanova, I.F. (2018). Book review: Chernenko, E.F. (2018). Energy Diplomacy. Moscow: Urait publ., 139 p. (In Russian). Vestnik RUDN. International Relations, 19 (3), 512-514. DOI: 10.22363/2313-0660-2019-19-3-512-514

В настоящее время, в условиях развития процесса глобализации и как следствие переплетения интересов участников международных отношений в различных регионах мира, весомая роль в проблеме понимания системы национальной и международной безопасности отводится ее энергетической составляющей. Однако многие страны не способны обеспечить собственную энергобезопасность без поддержки международного сообщества. Поэтому все больше стран вынуждено прибегать к использованию энергодипломатии как наиболее эффективного инструмента для обеспечения национальных интересов страны.

В этом ключе пособие для бакалавриата и магистратуры Е.Ф. Черненко - специалиста в области международных экономических отношений, энергетической политики, социально-экономиче- ских проблем развивающихся стран - представляется своевременным и востребованным.

Работа Е.Ф. Черненко позволяет получить детальную информацию относительно энергетической дипломатии в условиях технологического прогресса, адаптации энергетической сферы к новым условиям глобализации. В своей работе автор делает обзор трудов крупных исследователей в сфере геоэкономики и энергетики, российской и зарубежной научной мысли.

Понятие «энергетическая дипломатия» комплексное и сложное. В данном пособии внимание сосредоточено на внешнеполитических и внешнеэкономических аспектах обеспечения энергобезопасности государств. Так, автор отмечает, что «в настоящее время все более значимым становится энергетическое направление геоэко-

(C) Шириязданова И.Ф., 2019

(c) () This work is licensed under a Creative Commons Attribution 4.0 International License https://creativecommons.org/licenses/by/4.0/ 
номической дипломатии. Повышенное внимание к энергетической сфере в глобальном масштабе подтверждает общую тенденцию - экономизацию современной политики» [Черненко 2018: 28].

В связи с истощением традиционных источников энергии, таких как нефть, газ и каменный уголь, а также отсутствием к ним физического доступа у ряда стран растет интерес к развитию альтернативных источников энергии, таких как этанол, биотопливо, целлюлоза, приливно-отливные станции, солнечные батареи, ветровые установки, газогидраты, атомная и водородная энергетика. Успешной практикой производства и использования в автомобильной промышленности биоэтанола обладает Бразилия. Также заинтересованы в производстве биотоплива Германия, Литва, Казахстан, Украина. Россия готова войти в их число, особенно учитывая огромные территории страны, но пока неактивно вкладывается в рынок биологического топлива [Черненко 2018: 115]. И все же на сегодняшний день затраты на производство биотоплива зачастую превышают его энергетическое содержание. Еще одним аргументом против биотоплива является «загрязнение атмосферы в результате промышленного производства этанола» [Черненко 2018: 113].

Также озабоченность экологов и стран, обладающих разведанными запасами, «вызывают вредные последствия для окружающей среды от применения существующих методов добычи» сланцевой нефти и сланцевого газа [Черненко 2018: 121].

Автор рассматривает позицию России на мировом нефтегазовом рынке, ее энергетическую безопасность, которая непосредственным образом связана с национальной и военной безопасностью. Несмотря на то что Россия обладает богатейшей ресурсной базой, страна может войти в число государств, которые «не участвуют в мировом воспроизводственном процессе в должной мере, а лишь создают необходимые условия для других акторов международных экономических отношений, обеспечивая им стратегический эффект от внешнеэкономической деятельности, примыкая к чужим интеграционным воспроизводственным ядрам» [Черненко 2018: 26]. Поэтому в среднесрочной перспективе России «необходим переход от снабженческо-сбытовой на производственно-инвестиционную модель внешнеэкономических связей» [Черненко 2018: 64].

Однако у России благодаря выгодному географическому расположению есть возможность стать «ядром целого ряда производственно-коммерческих агломераций в энергетическом секторе глобальной экономики» [Черненко 2018: 65], «крупнейшим игроком на поле международных отношений в качестве их стабилизирующего фактора» [Черненко 2018: 45]. Все это позволило бы реально встать на путь развития инновационного и конкурентоспособного хозяйственного устройства страны.

В целом для дальнейшего устойчивого развития всей системы мировой экономики необходима новая концепция глобальной энергетической безопасности при активном привлечении инструментов энергетической дипломатии. Она предусматривает взаимовыгодное сотрудничество импортеров и экспортеров энергоресурсов, многоканальное развитие и совместные гарантии, когда все участники мирового энергетического рынка вынуждены учитывать потребности и возможности других акторов - как производителей, так и потребителей энергосырья.

Несомненным достоинством данного учебного пособия являются глубоко проработанные дидактические разделы. Задания для самостоятельной работы нацелены на развитие у студентов навыков системного анализа и формирования критического мышления. Эти навыки исключительно важны для профессионального становления будущих международников, регионоведов и экономистов, которые и являются целевой аудиторией данного пособия.

Поступила в редакцию / Received: 11.08 .2019 Принята к публикации / Accepted: 18.09.2019

\section{Библиографический список}

Черненко Е.Ф. Энергетическая дипломатия: учебное пособие для бакалавриата и магистратуры. М.: Издательство «Юрайт», 2018. 


\section{References}

Chernenko, E.F. (2018). Energy Diplomacy. Moscow: Urait publ. (In Russian)

Сведения об авторе: Шириязданова Ирина Фанилевна - кандидат исторических наук, старший преподаватель кафедры теории и истории международных отношений Российского университета дружбы народов (е-таil: irina.shiriiazdanova@gmail.com).

About the author: Shiriiazdanova Irina Fanilevna - PhD in History, Senior Lecturer, the Department of Theory and History of International Relations, RUDN University (e-mail: irina.shiriiazdanova@gmail.com). 